Annual Review'72

\title{
紡糸工学・構造・物性
}

向山鋭次

絎米工学・棈造・物性についての1971年のレビュー

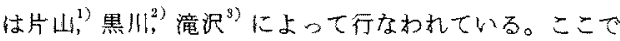
はそれ以降のむのについてレビェ一した。

この間で注目ず゙さことは個々に得られた研究成果を 集棈し“高分子の分子設計”に活がうとする試みがな

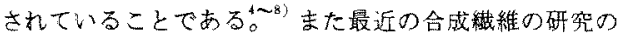
成果に関するレビュ一もある。紡系工学では基礎的研究 が引続きなされている一万，特殊紡系に関する研究も見

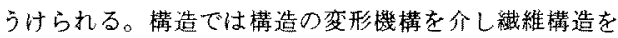
解明しようと古る報文が多く、繊維構造と物性の関係む 明らかにされつつある。また物性で沙非晶領域との関倸 を位置づけようとする報文も多い。これら個々の研究成 果は工学的体系化に大きな足跡を残すことになろう。な お本レビューは紙面に制限があるので概括的に紹介する にとどめる。詳紐は原文を参照願いたい。

\section{1. 紡采工学}

1.1. 基礎理諭むよびレオロジー

$\mathrm{PPなどの} 180^{\circ} \mathrm{C} に$ 枋けるキャビラリイ内での流動状態 が着色物の動静を観察することから解析さ机次式が成立 することがふされている。

$$
\begin{aligned}
& \alpha=178.5(0.9644) \Delta P_{e} / \sigma_{w}
\end{aligned}
$$

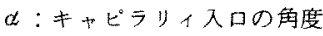

$$
\begin{aligned}
& \triangle P_{e}: \text { 入王力降下 } \\
& \mho_{w}: \text { キャビラリイ壁の剪断応力 }
\end{aligned}
$$

またキャピラリイ内正力分布とし/Dの閔係代もとら 孔ている。

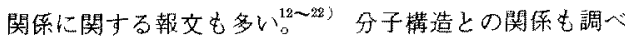

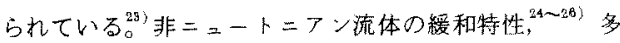
成分系の流陲状態が報告されている。 ダイがスリット形状をしたレオイータについて实験を行 ない通常のキャピラリィレオAータと同様にレオロジー 特性を解析し得ることを示している。

Fibers Spinning, Structures and Physical Preperties of Fibers

EI JI MUKOYAMA

東レ(株) 維研究所 所曼
アン流体の熱移動に関する研究 ${ }^{84,36}$ 溶融重合体の見掛け

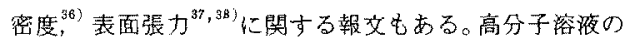
流動学動についても調べられている。

荻原らは高王用二重冈筒型レオメータを試作し高生で のレオロジー特性を調べている。

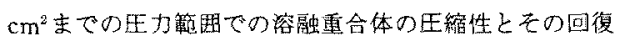
特性とを調べVoigt Model に類似した举動を示すこ と，非晶性重合体は結晶性のものに比べ王縮性が小さい 傾向を示すことを指摘している。

\section{2. 溶融紡杀}

M. Fujiyama らは溶融重合体のキャビラリイ内流動時 の弹性に関する特性を解析しメルトフラクチャとバラス 效果の発生要因解析を行なっている。

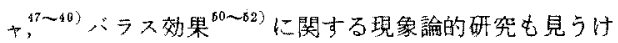
られる。北尾らは PEOの溶触紡系を試及最適紡系条件 を探索すると其に得られた未延伸系，延伸系の物性を調 ベている ${ }_{0}^{53,54)}$ F. C. Wampler らはPETを金を使すず にメルトプールからの真接紡系在試双ている。 チレンーコーポりオキサチレソ)テレフタレートの容

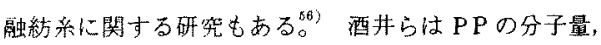
分子量分布を溶融時に制御する方法を見い出している。 また構造形成に閔する溶融紡采方法の影整についての報

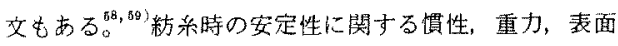
張力怙よび冷却，伸長粘度の影響についてはY.T.Shah

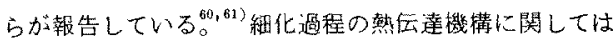
ヌセルト数とレイノルズ数の関保をより正確に求め上う とする試みがなされている。

P. Predecki ら注融点より低い温度での䊉系陚験を試 み高配向で透明なPE維䧽を得ている。その满造と物性 の関倸，掣系条件の最適化についても調べて㧍り與味深 $W_{0}^{68}$ 長野は高分子の溶融紡系に関寸方理諭が溶融金属紡 系にも邂用し得るか検討し近似的に合致することを認め ている。

\section{3. 溶液紡杀}

清造らはPET の湿式紡杀に関し効果的と考元られる 混合溶媒を見出し，それを用いて紡系試験を試及得られ

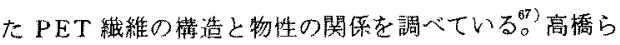




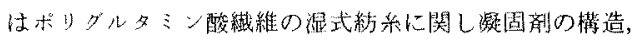
物性に与える影䇾を調べている。成国現象に関しては

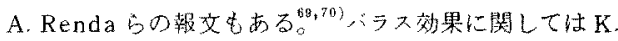

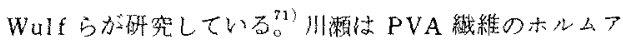
ルデヒドによる橋かけ反応に対与る紡系方法抢よび熱処

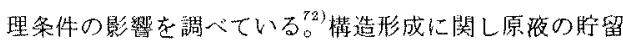

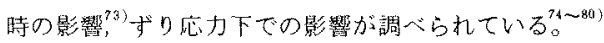

F.C.FrankbはPEのキシレン溶液を用い衝脬的に隫 射した時の構造，物性について实駼し與味ある知兒を得 ている。

\section{2. 構造}

\section{1 天然瀻維の構造}

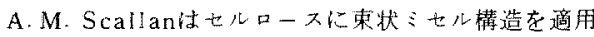
しその結晶の大きさ，結晶性などを計算している。 セル ロースI, 而の子ホーン・コンホィーンョンについては

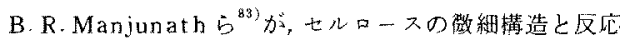

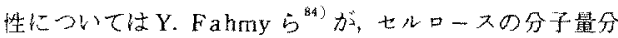
有については小售 ${ }^{86)}$ が研究している。セルロ一スの熱观

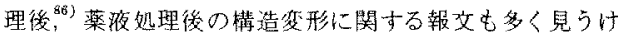

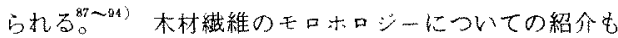

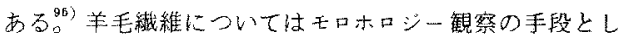
て凍結乾燥法が紹介さ㣗, 電㩆でその内部棈造が研究さ扎ている。 ンのコンホメーションについてはH. Ishikawa ら ${ }^{101)}$ コラーゲン䋐維の構造については豊田, ${ }^{(02)}$ I.V.Yannas

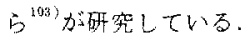

2.2 結晶構造, 結晶動力学

纖維構造が治角，小角X線，IR，ESR，SEM，光学 的・熱的手段などによりさらに研究されている゙

二相桧造と結びつけた報文もある。 yerは高分子の折りたたみに関し結晶頜域のみならず非 晶領域にも存在すると述べている。 は Kawai らが提出したラッラ府化と分子分别現象の結 びつけに関し異議を晿えている。 晶動力学についての研究もある。 法により結晶化速度を研究している。 满造! ${ }^{13 \sim 1193}$ 物性 ${ }^{119}$ 亿ついての研究, PEの結晶化, 結

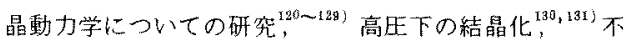
均一核生成に関する研究がある。 関しレーザ・タマンスペクトル, ダル浸透クロマトグ ラフイなどを適用した報交もある。

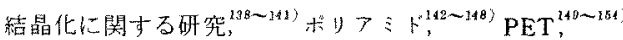
$\mathrm{PAN}^{166)}$ の結晶搆造，結晶化に開する研究も見らけられ る。その他各種結晶性高分子 $\left(\mathrm{POM}^{156,167)}\right.$ it

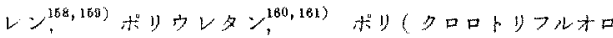

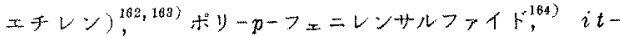

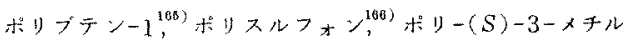

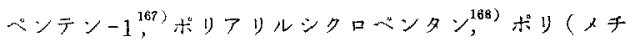
ルプロフェニルェーテル $)^{169)} \mathrm{PVC}^{170)}$ 天然ゴム, ${ }^{171,172)}$ ボ

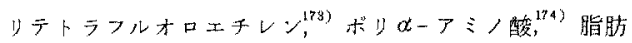

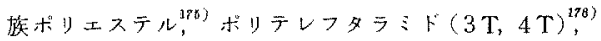
エチレンービニルアルコール共重合体, ${ }^{17)}$ ×チレンービ ールアセテートとェチレンーアクリル酸の共重合体 ${ }^{1783}$ 了 の結晶化，瀻維褠造についての報告がある。

2.3 延伸による構造変化

高速延伸中の高分子の構造変化を調べる手段か G.L. Wilksにより報告されている。 PPの結晶構造変形に

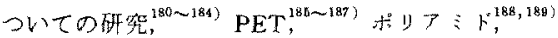

$P E^{190,191)}$ の棈造变形と物性の関保に関する研究がある。 その他各種結晶性高分子の菁造変形機棈, 物性の関保が

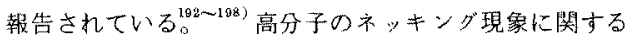

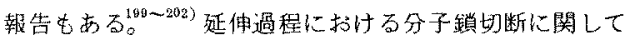
も報告されているがその機構が ESR や化学的分析手段 によって解明されつつある。

2.4 熱処理および膨潤処理による棈造変化

熱处理, 膨潤処理による構造变化についてはPET $T^{308 \sim 218)}$

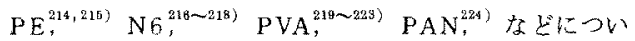
て研究されている。

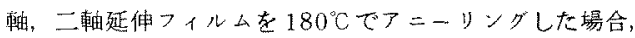
形成されたフィブリル状ラメラが一軸延伸サンプルでは 延伸方河と垂直にならんだが二軸延伸サンプルではラン ダムであることを示している。 黒川らは压延ナイロン フィラメントを高温で熱処理した場合压延面と直奥な側 面に変形带が発生し强伸度が减少することを見出してい $\mathrm{z}_{0}^{217>}$

2.5 その他

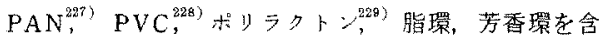
んだ PMA ${ }^{230)}$ ポリアミド ${ }^{2813}$ などのタティシティに関 する報文がある。

\section{3. 物性}

\section{1 力学的性買}

3.1 .1 引張り, 王樎, 弾性など

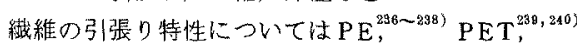
$\mathrm{PVA}^{241)}{ }^{241}{ }^{242}{ }^{242}$ 芳香族系ボリアミド ${ }^{2437}$ など結晶性高分

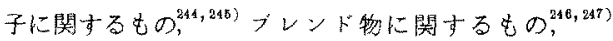

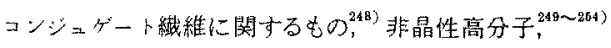
エラストマー ${ }^{256 〜 257)}$ 天然瀻維 ${ }^{288 〜 260)}$ に関するものなどの 他引掛角の影響 ${ }^{261)}$ 合系による影響 ${ }^{2629}$ が報告されている。

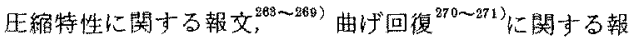
文もある。T，Itoは高生X線回折装置を開発し高时下だ 
の結晶格子の伸び㧍よび王力と容積の関係立求めてい る $^{263)}$ T. R. Manley らはポり(ホスフォートリルクロライ ト)の結晶弾性率を求め，この計算値が他の高分子結晶 のそれと良く一致することを報告している。

3.1 .2 タリープ㧍よび充力緩和

クリープの自動的測定方法に関してM.Kudrna の報 告がある。 ${ }^{273)} \mathrm{N} 66^{274 〜 276)} \mathrm{PET}$, $^{277 \sim 280)} \mathrm{PE}^{28(\sim 284)} \mathrm{PP}^{285 \sim}$ 288) $\mathrm{PVF}^{2897} \mathrm{PAN}^{290,291)} \mathrm{PVA}^{\text {(392) }}$ ビスコースレーヨン およびポりカ一ボネート，ポリスチレンなど非晶性高分 $子^{239+305)}$ 加䟽ゴム ${ }^{306)} \neq \underbrace{307 \sim 309)}$ などに関するクリーブ や応力緩和の举動が研究されている。

\section{1.3 動的性犋}

動的粘弾性測定装盖に閶する報告が多い。 GillhamらはTorsional BraidとTorsional Pendulumについで, 永沼らはDynamic Spring Analysisについて ${ }^{312)}$ 報告している。PP $P^{315\}}$ ポリウレタ

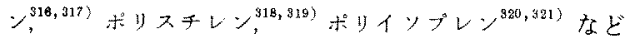
の動的性質が報告されている゙日2,329)

3.1 .4 瘏労，破㙹

疲労，破壊に関してはボりアミド, ${ }^{324 ー 3293} \mathrm{PET}{ }^{530)}$ およ

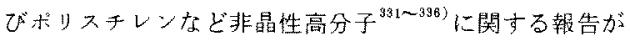
ある。S.Kaufmann はボyフミドフィラメントの延伸 中の破断について系統的に研究している。

3.1 .5 取繀, 摩擦

収樎に関してはPP , $^{387 ー 339)} \mathrm{PET}^{340)} \mathrm{PAN}^{341)}$ 拈よび二 成分系 ${ }^{342,393}$ について報告があり，摩摖に閏しては測定

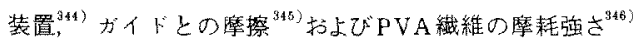
などについての報告がある。

\section{1 .6 異方性}

$\mathrm{PE}^{346 \sim 361\rangle} \mathrm{PP} \mathrm{P}^{362 \sim 356\rangle} \mathrm{PET}^{356 j} \mathrm{N6}^{357\rangle} \mathrm{POM}^{353,359\}}$ お5

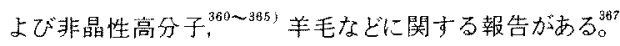

〜321 粟屋らはTダイ製膜 P P フィルムの複屈折が營光法 による配向度と直線関係に变ることを報告している。

\section{2 熱的性啠}

\section{2 .1 融 解}

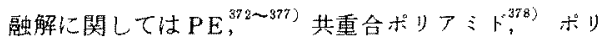
エステル ${ }^{378,380)} \operatorname{trans}-1,4$-ポりイソブレン, ${ }^{381)}$ itーポ

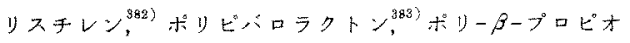
ラクトンやポリーยーカプロラクトン ${ }^{384}$ などについての

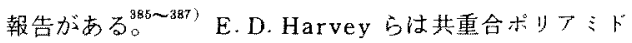
の共結晶化について融解举動の観点から詳しく模討して いる。

$3.2 .2 \mathrm{Tg}$, 転移点

G. Salee $\mathrm{Tg} の$ 迅速測定法について ${ }^{388)}$ A.J

Kovacs bは熱的転移の光学的解析法について述べてい る ${ }_{0}^{389)}$ T. Noseはホール理論を適用してTgに関する研究
在行なっている。

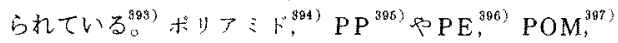

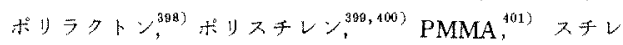
ソーMMA 共重合体, ${ }^{402)}$ ポリウレタン, ${ }^{403)}$ ポリソシウム〉

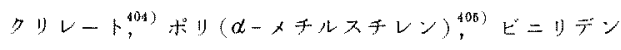
クロライトとアクリロニトリル共重合体, ${ }^{406)}$ 七ルロ一ス

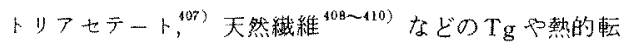
移垷象に関する報告がある。

3.2 .3 比熱, 比容, 熱层導率

比熱については $\mathrm{POM}^{4(3)}$ ポリスチレン,14) $\mathrm{PMMA}^{415)}$

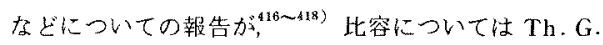

Scholte の報告が, 熱伝導については O. Yamamoto ら ら $^{420,421)}$ の報告がある。

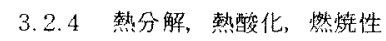

熱分解についてはPAN ${ }^{429 \sim 438)}$ セルロ一ス系, 弗菜含有重合体, ${ }^{439,434}$ PMMA, ${ }^{\text {495) }}$ ポリィタキシリレンフ シハミド, $\mathrm{PEO}^{437\rangle} \mathrm{PVC}^{4387}$ などについての報告があ る。またJ. At kinsonは熱分解の動力学的考察を行なっ ている。 熱酸化に関してはポりイミド, ${ }^{433} \mathrm{PE}{ }^{444)}$

PET ${ }^{145\}}$ N6 $^{466}$ についての報告がある、燃焼性につい ての報告も見らけられる。

\section{3 電気. 光学的性算}

電気的性留に関してはボリーNービニルカルハン゙ールの

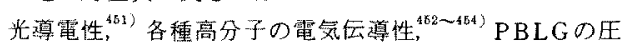

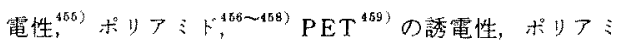
トなどの帯電性, ${ }^{40 \sim 699}$ ポリつミドの微科構造と等電点の 関保 ${ }^{464)}$ について報告がある。光学的性質に関しては

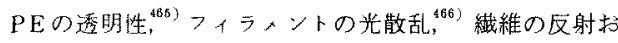
よび透過特性, (67) 䅧物状の光沢に関寸る $^{488 \sim 431)}$ 報告があ 万。

\section{4 低分子との相互作用}

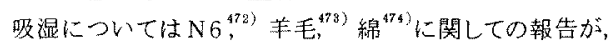
羊毛の変性プロティン溶夜中のS-S学動についてはW， G. Crewtherの報告がある。低分子の㖟着，应敬に関

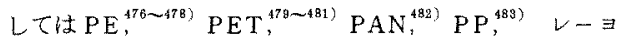

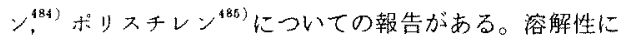
関してはホルムフルデヒド共重合体瀻維 ${ }^{486}$ セルロース

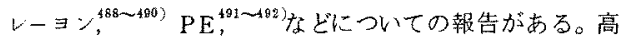
分子溶液の熱的特性についての報告も見うけられる。 ぬれ挙動に関しては中村らが流動電位法による測定方法

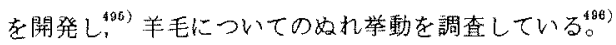
根本らは高分子フィルムの水中油滴の奴れについて, 俈貫は瀻維集合体のぬ机に関して報告している。呧分子 との相互作用による微細精造の研究に関してはPET ${ }^{490}$ 604) ポリアミド,

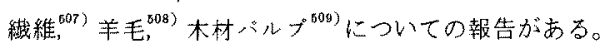




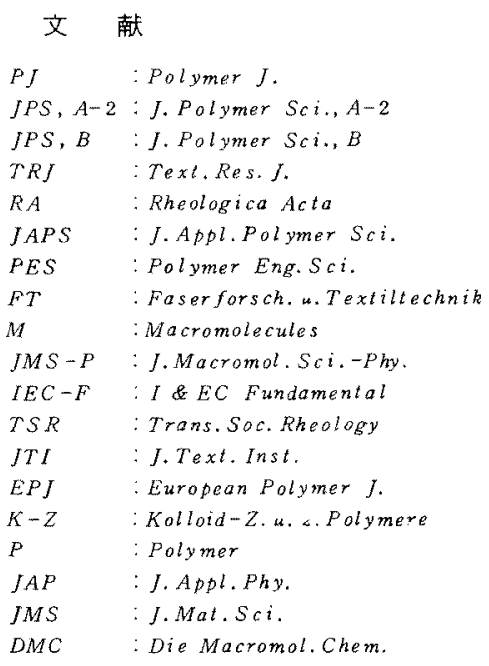

1) 片山；絨維と工業，4，585(1971)

2) 墨川; 緒維上工策, 4, 588(1971)

3) 澺沢; 乘稚上工栄, 4, 593(1971)

4) 温鼠的; “高分子の分子設計”（培風館，1972）

5)真島占；离分子，20，654(1971)

6)赫木；高分子, 20,664(1971)

7) 相宅; 絨維上工策, 4, 496(1971)

8) 问山; 䄉䊒而学, 25, 260(1972)

9) Textile Progress, 3, (1971)

10) T.F.Ballenger, J. L. White; JAPS, 15, 1949(1971)

$11)$ C.D. Han, M.Charles:TSR, 15, 371(1971)

12) 石田与：高化。 $28,834(1971)$

13) 志賀的; 吂化，28,839(1971)

14) 片衙占; 高他，28，676(1971)

15) G.P.Giuliani, A. De.Chirico; $J M S-P, B 5,429(1971)$

16) V.A.Zosel: $K-Z, 246,657(1971)$

17) D.R.Beech et al. ; $P, 13,73(1972)$

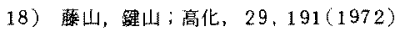

$19)$ D. P. Thomas ; PES, 11, 305(1971)

20) E.A.Collins, A.P. Metzger; PES, 11,446(1971)

21) W. Conti, E. Sorta;EPJ, 8,475(1972)

22) 荻原占;高化，28，830 (1971)

23) M. Hoffmann ; $D M C, 153,99(1972)$

24) J.S.Dodge, 1, M. Krieger ; TSR, 15, 589(1971)

25) K. H. Lee, R.S. Brodkey ; TSR, 15, 627(1971)

26) J.M. Dealy ; $P E S, 11,433(1971)$

27) N. Nakajima et al, ; $T S R, 15,647(1971)$

28) A. Plochocki : JAPS, 16,987(1972)

29) Z.Sobotka; JMS $-P, \mathbf{B} 5,393(1971)$

30) 改朋；离化，29,270(1972)

31) C. D.Han ; JAPS, 15, 2567(1971)

32) idem; ibid, $15,2579(1971)$

33) idem; ibid, 15, 2591(1971)

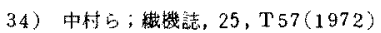

35) W. H. Suckow et al, ; PES, 11,401(1971)
36) A. Rudin, A.G. Vlass chaert ; $T S R, 15,551(1971)$

37) T. Nose; $P J, 3,1(1972)$

38) G. L. Gaines, Jr. ; $P E S, 12,1(1972)$

39) A. S. Lodge, Wu. Y-Jing; $R A, 10,539(1971)$

40) R.C.Little: IAPS, 15, 3117(1971)

41) J. H. Elliott, F.S. Stow; 15, 2743(1971)

42) P. Peyser, R.C.Little ; JAPS, 15, 2623(1971)

43) 荻原占; 商化, 28,825(1971)

44) K.L. Devries, D.K. Baekman ; JPS, B, 9, 717 (1971)

45)山口, 大留；离化, $28,623(1971)$

46) M.Fuji yama, H. Awaya ; JAPS, 16, 275(1972)

47 ) C.D.Han, R. R. Lamonte ; PES, 11, 385(1971)

48) idem; ibid, 12, 77(1972)

49) o. Bartos, J, Holomek; PES, 11, 324 (1971)

50) C. D. Han, K.U.Kim ; PES, 11, 395(1971)

51) C.D. Han, J.C.Yu. ; PES, 12, 81(1972)

52) F. N. Cogswell; PES, 12, 64(1972)

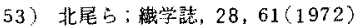

54) 北电占; 緎学誌, 28,221(1972)

55) F. C.Wampler et al, ; JAPS, 16, 99(1972)

56) E. Leibnitz et al.;FT, 22,541(1971)

57) 酒井与; 亮化, 28，868(1971)

58) M. R. Kantz et al. ; JAPS, 16, 1249(1972)

59) 関, 星野; 高化, 28,902(1971)

60) Y.T.Shah, J.R.A. Pearson; IEC-F,11,150(1972)

61) idem; ibid, 11, 145(1972)

62) 清水的; 䋞機誌, 25, T34(1972)

63) D. Acierno et al, ; JAPS, 15, 2395(1971)

64) J. M. Charrier, R. J.P. Ranchoux;PES, 11,381(1971)

65) P.Predecki, W. O. Statton ; JPS, B, 10, 87(1972)

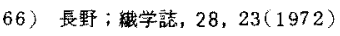

$67)$ 清造、平; 䋱学誌, $28,15(1972)$

68) 高樀与; 織学誌, 28, 112(1972)

69) A. Rende ; JAPS, 16, 585(1972)

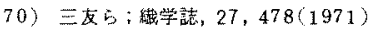

71) K. Wulf et al.;FT, 23, 14(1972)

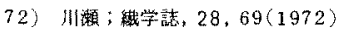

73) S. Fujishige; JPS, A-2, 10, 265(1972)

74 ) 茫井，浅野；商化，29，317(1972)

75) 近藤与; 滈化, 28,507 (1971)

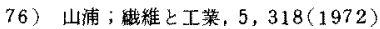

77) K. Yamaura et al. $; K-Z, 248,883(1971)$

78) idem; ibid, 248,893(1971)

79) S.Matsuzawa et al. $; K-Z, 250,20(1972)$

80) 近藤 $b$ : 皂化, $29,131(1972)$

81) F.C.Frank et al. ; $P, 12,467(1971)$

82) A. M. Scallan; TRJ, 41, 647(1971)

83) B.R.Manjunath, N. Peacock ; JAPS, 16, 1305(1972)

84) X. Fahmy, F.Mobarak; JPS, B, 9, 767(1971)

85) 小會；载維上工策，5，9(1972)

86) A. M. Hindeleh, D.J. Johnson ; $P, 13,27(1972)$

87) E. Roffael:FT, 22, 429(1971)

88) T. L. Vigo et al. ; $T R J, 42,96(1972)$

89) S.G. Shenouda, A. Vis wanathan ; JAPS, 16, 395 (1972)

90) idem; ibid, 15, 2259(1971)

91) B.R.porter, M. L. Rollins ; JAPS, 16, 217(1972) 
92) idem; $i b i b, 16,237(1972)$

93. P. K. Ray ; TRJ , 41, 944(1971)

94) S. Banclurjan et al. ; FT, 22, 477(1971)

95）湶田；践䊒上工莱，5，14(1972)

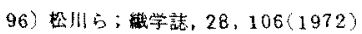

97) 田川; 維維之工菜, 4, 432(1971)

98) J.A.Swift; $J T I, 63,64(1972)$

99) J.D. Leeder, J.H. Baradbury ; $R J, 41,563(1971)$

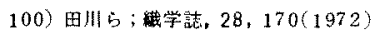

101) H. Ishikawa, K. Hirabayashi ; 站学誌, 28, 167(1972)

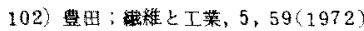

103 I. V. Yannas, C. Huang; JPS, A-2, 10, 577(1972)

104) A. Peterlin: $T R J, 42,20(1972)$

105) V.R.Perret, W. Ruland; $K-Z, 247,835(1971)$

106) S. Y. Hobbs, G, I. Mankin ; JPS, A-2, 9, 1907 (1971)

107) C. P. Sharma ; $T R J, 41,712(1971)$

108) P. H. Lindenmeyer (高見浩訳)；离分子，21，309(1972)

109) B. Wunderlich, A.Mehta ; $D M C, 153,327(1972)$

110) T. Ishinabe, K. Ishikawa ; PJ, 3, 300(1972)

111) 高井，金子；高化，29，336(1972)

112) 岩没占；高化, 29, $139(1972)$

113) D. T. Grubb et al. ; JMS, 7, 131(1972)

114 D. J. Priest ; JPS, A-2, 9, 1777(1971)

115) A.Keller, Y. Udagawa ; JPS, A-2, 9, $1793(1971)$

116) A. Keller et al, ; JPS, A-2, 9, 1807(1971)

117) M. Satou et al. : JPS, $\mathrm{A}-2,10,835(1972)$

118) A. Peterin et al, ; JPS, A-2, 9, 583(1971)

119) 捠田; 桡維上工菜, 4, 387(1971)

120) A. Booth, J. N.Hay ; $P, 12,365(1971)$

121) A. Keller et al.; JPS, A-2, 10, 239(1972)

122) A. Keller, Y. Udagawa ; JPS, A-2, 10, 221(1972)

123) E. Ergoz et al, ; $M, 5,147(1972)$

124) R.G.Crystal, J.H. Southern ; JPS, A-2, 9, 1641(1971)

$125)$ V. B. Heise et al. : $K-Z, 250,120(1972)$

126) Z, Mencik et al.; JPS, A-2, 10,507(1972)

127) D.C. Bassett, J.M. Phillips ; $P, 12,730\{1971\}$

128) M. Beris, E. B.Crellin : $P, 12,666(1971)$

129) S. H. Carr ; JPS, A-2, 10, $755(1972)$

130) J.F. Jackson et al. ; JPS, B, 10, 207(1972)

131) J. L. Kardos et al. ; JPS, A-2, 9, $2061(1971)$

132) K. Hara, H. Schonhorn ; JAPS, 16, $1103(1972)$

133) 高樮的; 高化, $28,973(1971)$

134) 高橋占; 高化, 28, $978(1971)$

135) M. J. Gall et al ; $P, 13,104(1972)$

136) I. M. Ward, J.Williams ; JMS - P, B 5, 693(1971)

137) V. A. Schönfeld et al.; $K-Z, 250,102(1972)$

138) A.T. Jones ; $P, 12,487(1971)$

139) 栵屋; 高化, 29, $101(1972)$

140) R. J. Samuels, R.Y.Yee ; JPS, A-2, 10,385(1972)

141) 生島占; 高化, 29, 186(1972)

142) E. Turska, S.Gogolewski ; $P, 12,616(1971)$

143) idem; ibid, 12,629(1971)

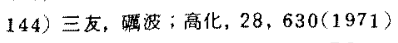

145) M. G. Nor tholt et aI, ; JPS, A-2, 10, 191(1972)

146) P. Dreyfuss et al.; JPS, A-2, 10,857(1972)

147) E.D.T.Atkins et al.; JPS, A-2, 10, 863(1972)

148) T. Michael, H. Rudolf ; FT, 23, 21(1972)
149) K. Nakamura et al, ; JAPS, 16, 1077 (1972)

150) A. Wlochowicz et al, :EPJ, 8, 313(1972)

151) D.C.Prevorsek, J.P. Sibilia ; JMS -P, B5, 617(1971)

152) V. G. Konrad, H. G. Zachmann; $K-Z, 247,851$ (1971)

153) A. J. Melveger ; JPS, A-2, 10, 313(1972)

154) G.S. F. Russell, P. S. Pillai ; $K-Z, 250,2(1972)$

155) V. G. Hinrichsen, H.Orth; $K-Z, 247,844(1971)$

156) 高橋占; 高化, 29, 331(1972)

157) T. Takahashi, N. Ogata ; JPS, B, 9, $895(1971)$

158) J.Dlugoss ; JMS. 7, 142(1972)

159) J. B. Helms, G.Chatla; JPS, A-2, 10, $761(1972)$

160) Y. Saito et al. : $P J, 3,113(1972)$

161) 中山; 高分子，21，25(1972)

162) J.P. Sibilia et al. ; JPS, A-2, 10, 549(1972)

163) Y. Miyamoto; $P J, 3,122(1972)$

164) B. J. Tabor : $E P J, 7,1127(1971)$

165) K.S.Sastry, R.D.Patel : EPJ、8, 63(1972)

166) K. J. Ivin, N. A. Walker ; JPS, B, 9, 901(1971)

167) V.Petraccone et al.;EPJ, 8, 99(1972)

168) idem; ibid, $8,107(1972)$

169) R. Chujo et al, ; PJ, 3, 289(1972)

170) A. J. Brunner ; JPS, B, 10,379(1972)

171) P. J.Phillips, E. H. Andrews ; JPS, B, 10, 321 (1971)

172) A.Keller, E. Martuscelli ; DMC, 151, 189(1972)

173) D. M. Pinkerton; JPS, A-2, 10, 473(1972)

174) 小西，黒川；学誌，28，83(1972)

175) T. Kanamoto, K. Tanaka ; JPS, A-2, 9, 2043(1971)

176) H.K.Livingston, R.L.Gregory ; JPS, A-2, 9, 2081 (1971)

177) 轱本5；高化，28，610(1971)

178) G. Kortleve et al.; JPS, A-2, 10, 123(1972)

179) G. L. Wilkes et al.; JPS, A-2, 9, 2151(1971)

180) 木下滈化, 28, 531 (1971)

181) 高原战学誌, $27,338(1971)$

182) S. Nomura et al.; JPS, A-2, 9, 1991 (1971)

183) H. Tanaka et al.; JAPS, $16,441(1972)$

184) S. Okajima et al.; JPS, B, 9, 797 (1971)

185)松本战絨学誌, $28,179(1972)$

186) 松本占; 㙨学誌, $28,189(1972)$

187) C. J. Heffelfinger, E. L. Lippert ; JAPS, 15, 2699 (1971)

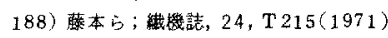

189) B. K. Daniels ; JAPS, 15, 3109(1971)

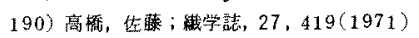

191) 朱, 北丸；高化，29，214(1972)

192) 日比方; 瀻学誌, 28, 204(1972)

193) 赤羽, 望月；高化，28，577(1971)

194) M. Yamamoto, J.L. White ; JPS, A-2, 9, 1399 (1972)

195) I. R. Hardin et al.; JPS, B, $9,771(1971)$

196) T. Asada et al, ; $P J, 3,350(1972)$

197)增田：高分子, 21，160(1972)

198) H. Obata, H.Kanetsuna ; JPS, A-2, 9, $1977(1971)$

199) 和田；高分子, $21,352(1972)$

200) G.P. Andrianova et al.; JPS, A-2, 9, 1919(1971)

201)小标; 械学譡, $28,197(1972)$

202) C.C.Hsiao, S.R.Moghe ; JMS -P, B 5, 269(1971)

203) 加薀ら; 高化, 28, 687(1971) 
204) 加藤占; 禹化, $28,693(1971)$

205) 木下5;亩化, 28,864(1971)

206) R. Natarajan, P.E.Reed ; JPS, A-2, 10, 585(1972)

207) K. L. Devries et al.; JPS, A-2, 9, 605(1971)

208) 伊藤, 阙泉; 日化, No.1, 142(1972)

209) E. Ito et al.; $K-Z, 248,899(1971)$

210) J.J.Klement, P. H. Geil ; JMS - P, B 5, 505(1971)

211) idem; ibid, B 5, 535(1971)

$212)$ 松本战学誌, 27,516(1971)

213) S. Fakirov et al, ; FT, 22, $554(1971)$

214) R. Hosemann et al.; $K-Z, 247,824(1971)$

215) D. A. Blackadder, J. S.Keniry ; JAPS. 16, 1261(1972)

216) 㙫本5; 日化, No, 2, 454(1971)

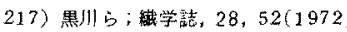

218) 赤羽与；高化, $28,573(1971)$

219）亦雨，望月；高北，28，568(1971)

220) 赤羽，望月；高化，28，594(1971)

221) 䠌原, 安田；䯩化，28,906(1971)

222) 日比方; 機学誌, 28，45(1972)

223) 日比方; 緎学詰, $28,53(1972)$

224) M. Sotton, A.M. Vialard; $T R J, 41,834(1971)$

225) Y.Hase, P.H.GeII;PJ. 2, 560(1971)

226）泉山，金絾；高化, $28,537(1971)$

227) Y. Inoue, A. Nishiokt ; $P J, 3,149(1972)$

228) X. Inoue et al,; $P J, 3,246(1972$

229) S. Brückner et al.; EPJ, 7, 1473(1971)

230) J. Nishino, H. Nakahata; $P J, 2,555(1971)$

231) G. Montaudo et al, ; $M, 5,197(1972)$

232) K. Matsuzako et al.; JAPS, 16, 15(1972)

233) N.W. Johnston, P.W. Kopf ; $M, 5,87(1972)$

234) A.R. Srinivasan, V. S.R.Rao; JPS, A-2, 10,693 (1972)

235) 大成；高分子，21，260(1972)

236) N. H. Ladizesky, I. M. Ward ; JMS -P, B5, 661(1971)

237) idem; ibid, B 5, 745(1971)

238) P. B. Bowden, J. A. Jukes; JMS, 7, $52(1972)$

239) R. J. Samuels ; JPS, A-2, 10,781(1972)

240) A. Blazej et al,;FT, 23, 85(1972)

241) II頪；截学志，28，37(1972)

242) C. Garbug lio et al.; JAPS, 15, 2487(1971)

243) G.S.F. Russell; TRJ, 41, 861(1971)

244) Y. Hase, P.H.Geil ;PJ, 2, $581(1971)$

245) 清造，下村；高化，28，563(1971)

246) 井手占; 高化, 29，265(1972)

247) 井手的; 语化, 29, 259(1972)

248) A, El. Shiekh et al, ;TRJ, 41,916(1971)

$249)$ C.B. Crowet et al.; $J M S, 7,176(1972)$

250) R. E. Robertson, C.W. Joynson ; JAPS, 16,733 (1972)

$251)$ A. N. Gent, A. G. Thomas; JPS, 10,571(1972)

252) K. Ito; $T S R, 15,389(1971)$

253) J.E. Jones et al,; TRJ, 41, 900(1971)

254) H. Oberst, W. Retting ; JMS $-P, \mathrm{~B} 5,559$ (1971)

255) J. Ferguson, D. Patsavoudis ; EPJ, 8, 385(1972)

256) T. L. Smith, W.H.Chu; JPS, A-2, 10, 133(1972)

257) R. T. Brown et al.; JPS, B, 10, 327(1972)

258) D.S. Varma, R.K. Sarkar ; TRJ, 41,610(1971)
259) H.Halboth, G.Heidemann; $T R J, 41,860(1971)$

260) E. Uhlig ; FT, 22,610(1971)

$261)$ 近田占; 阵学誌, 25, T65(1972)

262) F. Figucia et al, ; $P E S, 11,289(1971)$

263) T. Ito, H.Marui ; $P J, 2,768(1971)$

264) H. Li. D. Pugh et al, ; PES, 11, 463(1971)

265) F. De. Candia, L. Amelino; JPS, A-2,10, 715(1972)

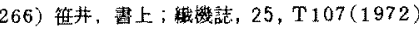

267) E. Sebestyen, T. S. Hickle ; $J T I, 62,545(1971)$

268) J.R.Collier et al.;PES, 11,453(1971)

269) 伊藤; 离分子, $21.82(1972)$

270) C.M. V.Wyk, J.J. Venter; JTI, 62, 655(1971)

$271)$ J.C.Guthrie; JTI, 62,615(1971)

272) T. R. Manley, C.G.Martin;P, 12,775(1971)

273) M.Kudrna ; JMS-P, B 5, 415(1971)

274) H.G.olf, A.Peterlin; JPS, A-2, 9, 1449(1971)

275) H.G.Olf ; JPS, A-2, 9, 1851(1971)

276) H.G. Olf, A.Peterlin ; JPS, A-2, 9, 2033(1971)

277) C.D. Armeniades, E. Baer ; $J P S, A-2,9,1345(1971)$

278) A. Hiltner, E. Baer ; $P J, 3,378(1972)$

279) U. Eichhoff, H.G. Zachmann; FT, 22, 395(1971)

280) E. Sacher ; JMS-P, B 5, 739(1971)

281) T. Oda, R. S. Stein ; JPS, A-2, 10,685(1972)

282) M.J.Hill, A.Keller ; JMS-P, B5, 591(1971)

283) M.W. Darlington, D.W. Saunders ; JMS $-P, \mathrm{~B} 5,207$ (1971)

284) L. S. Priss, V. S. Popov; JMS-P, B5, 461(1971)

285)松本，沙野；瀻学誌，28，1(1972)

286) A. Kobayashi et al,: JAPS, 15,3009(1971)

$287)$ P. P. Benham, S. J.Hutchinson ; PES, 11, 335(1971)

288) J.S. Higgins et al.; $P, 13,157(1972)$

289) N. Kawasaki, T. Hashimoto ; JPS, A-2, 9, 2095(1971)

290) 南的; 高化, 29,114(1972)

291）南占; 高化, 29, 109(1972)

292) J.R. Demember et al, ; JPS, B, 10, 385(1972)

293) W. Zurek, J.Godon ; TRJ, 41, 984(1971)

294) I. V.Yannas, M. J. Doyle ; JPS, A-2, 10. 159(1972)

295) 1. V. Yannas, A.C. Lunn ; JPS, B, 9, 611(1971)

296) 1. V.Yansas et al, ; JMS - P, B5, 487(1971)

297) D. G. Legrand ; TSR, 15, 541(1971)

298) C. B. Bucknall, D. Clayton; JMS, 7, 202(1972)

299) K.Murakami et al, ; PJ, 2, 698(1971)

300) 画村方；高化，28，843(1971)

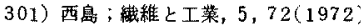

302) D. Machin, C.E.Rogers ; JPS, A-2, 10, 887(1972)

303) J. Kolarik, J. Janacek ; JPS, A-2, 10, 11(1972)

304) J,Ferguson et al.;EPJ, 8, 369(1972)

305) V. Heidinsgs feld et al, ; JAPS, 15, 2447(1971)

306) L. A.Wood, G.W. Bullman ; IPS, A-2, 10, 43(1972)

307) 根本号; 㺃学誌, 27, 473(1971)

308) R. Shishoo;TRJ, 42, 33(1972)

$309)$ H. D. Weigmann, C. J. Dansizer ; TRJ, 41, 576(1971)

310) J. Hrouz, J. Janacek ; JMS - P, B 5, 2,45 (1971)

311) J. K.Gillham, M. B. Roller ; PES, 11, 295(1971)

$312)$ J.P. Walters ; TR J, 41,857(1971)

$313)$ 永照 5 ；离化，29，105(1972)

314) P. G. Wapner, W. C. Forsman; TSR, 15, 603(1971) 


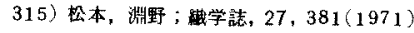

316) J.L. Illinger et al. ; PES, 12, 25(1972)

317) D. Shuh, S.L.Cooper ; PES, 11, 369(1971)

318) T. Fujimoto et al, $P J, 3,181(1972)$

319) T. Masuda et al.; PJ, 3, 92(1972)

320) V. Baresova et al, JPS, A-2, 10,945(1972)

321) 針間的; 高化, $29,245(1972)$

322) 針間，如柳；高化，29，240(1972)

323) P. Mason, J. Unsworoh $; K-Z, 249,1101(1971)$

324) S. Kaufmann : FT, 22, 406 (1971)

325) idem; ibid, 22, 463(1971)

326) idem: $i b i d, 22,496(1971)$

327) J. M. Thorp ; $J T I, 62,686(1971)$

328) V. Zilvar; JMS-P, B5, 273(1971)

329) 黒川 方; 学誌, 27, 457(1971)

330) P. I. Vincent ; $P, 12,534(1971)$

331) V.Havlicek, V. Zilver ; JMS-P, B5, 317(1971)

332) E. Foden; JAPS, 16, 519(1972)

333) R.J.Bird et al. : P, 12, 742(1971)

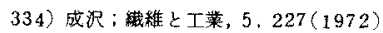

335) L. J. Broutman et al. : PES, 12,150(1972)

336) B.E. Nelson, D.T.Turner; JPS, B, 9, 677(1971)

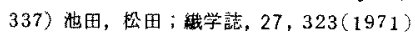

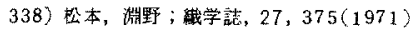

339) H. Tanaka et al. ; JPS, B, 9, 723(1971)

340) 石錦 5 ; 高化. 29, 56(1972)

341) H. J. Jacobasch et al, ;FT, 23, 42(1972)

342) S. Backer, S.Batra;TRJ, 41, 1008(1971)

343) G. Ronca, E. Sorta ; $F T, 23,55(1972)$

344) 知野, 输木; 俄学誌, $27,366(1971)$

345) 岩木5; 織機梳, 24, T $159(1971)$

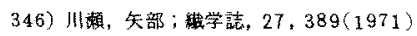

347) 如野，铪木; 轵学誌, 27, 328(1971)

348) C.C.Cheng, K. E. Ducket t ; TRJ, 42, 51(1972)

349) V.W.Glenz, A.Peterlin ; $K-Z, 247.786(1971)$

350) Y. Fukui et al,;PJ,3,100(1972)

351) V. B.Gupta, I. M. Ward ; JMS $-P, B 5,629(1971)$

352) 高原占; 辑学誌, 27,349(1971)

353) 聚星, 五十部; 离化, 29,196(1972)

354) 1.Diacik et al.;FT, 23, 70(1972)

355) D. Roylance, M. Roylance ; JPS, B, 10, 273(1972)

356) I. H. Hall ; $P, 13,69(1972)$

357) M. Jambrich et al.; FT, 23, 28(1972)

358) H. W. Starkweather et al.; JPS, B, 9, 623(1971)

359) T. Kitagawa, A. Tanaka; JPS, B, 9, 579(1971)

360) D. Heikens at al.; $P, 12,797(1971)$

361) M.Kashiwagi , I.M. Ward ; $P, 13,145(1972)$

362) M. Kashiwagi et al.; $P, 12,697(1971)$

363) S. Raha, P.B. Bowden ; $P, 13,174(1972)$

364) J.Pohrt ; JMS -P, B 5, 299(1971)

365) S. L. Samuels, G.L.Wilkes ; JPS, B, 9, $761(1971)$

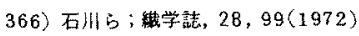

367) E.M. Bradbury et al.; $M, 5,8(1972)$

368) M. J.Folkes et al, ; $, 12,793(1971)$

369) 住田 5 ; 俄学誌, 28,45(1972)

370) B. F. Conaghan, S. L. Rosen : PES, 12, 134(1972)

371) T. Hashimoto, R. S. Stein; JPS, A-2, 9,1747(1971)
372) W. G. Harland et al.; $P, 13,13(1972)$

373) V.E.W. Fischer, G. Hinrichsen; $K-Z, 247,858(1971)$

374) O.M. Griffin ; PES, 12,140(1972)

375) D.W. Sundstrom, C.C. Young ; PES, 12, 59(1972)

376) S. B. Clough ; JAPS, 15, 2141 (1971)

377) V.A. Fra, J. J. Lindberg ; JPS, A-2, 10, 937(1972)

378) E. D.Harvey, F. J.Hybart ; $P, 12,711(1971)$

379) M.Pietrzak, J.Kroh;EPJ, 8, 237(1972)

$380) \mathrm{K}$. Onder et al. ; $P, 13,133(1972)$

381) E. Martuscelli ; $D M C, 151,159(1972)$

382) P. J.Lemstra et al. , JPS, A-2, 10, 823(1972)

383) C.Borri et ai,;EPJ, 7, 1515(1971)

384) V.Crescevzi et al.;EPJ, 8, 449(1972)

385) A.R. Shaltz, C.R. M ccullough ; JPS, A-2,10, 307 (1972)

386) A. Takahashi et al.; $P J, 3,207(1972)$

387) T. Korenaga et al, ; PJ, 3, 21(1972)

388) G. Salee ; JAPS, 15, 2049(1.971)

389) A. J.Kovacs, S. Y. Hobbs ; JAPS, 16, 301(1972)

390) T. Nose ; PJ, 2, 445(1971)

391) idem; ibid, 2, 427(1971)

392) idem ; ibid, 3, 196(1972)

393) S.C.Sharma et al,; JPS, B, $10,345(1972)$

394) G.A.Gordon ; JPS, A-2, 9, $1693(1971)$

395) M.Pegoraro et al, ;EPJ, 7, $1709(1971)$

396) P.P.A. Smit ; $K-Z, 250,27(1972)$

397) Y.Aoki et al.; $P J, 2,502(1971)$

398) J. V. Koleske, R. D. Lundberg ; fPS, A-2, 10, 323 (1972)

399) S. Ichihara, A. Komatu ; PJ, 2, $530(1971)$

400) G.W. Miller ; JAPS, 15, 2335(1971)

401) S. Bywater, P.M. Toporowski ; $, 13,94(1972)$

402) K. Ogura, H. Sobue : $P J, 3,153(1972)$

403) R.W. Seymour, S.L. Cooper ; JPS, B, 9, 689(1971)

404) A.Eisenberg et al.; JPS, A-2, 9, 2131(1971)

405) S. Ichihara et al.; $P J, 2,650(1971)$

406) M. Kryszewski, M. Mucha, JAPS, 15, 2687(1971)

407) S. Nakamura et al.; JPS, B, 9, 591(1971)

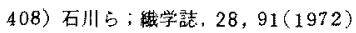

409) C. Delisi, M. H. Shamos ; JPS, A-2, 10, 673(1972)

$410)$ D. S. Varma, R. K. Sarkar ; JAPS, 15, 2173(1971)

411) K.Matsushige et al, $P J, 3,166(1972)$

412) W. Wrasidlo ; JPS, A-2, 9, 1603(1971)

413) V.H.Wilski ; $K-Z, 248,867(1971)$

414) S. Ichihara et a1, ; $P J, 2,644(1971)$

415) V.R.Hof fmann, W. Knappe ; $K-Z, 247,763(1971)$

416) V.K. Eiermann et al.; $K-Z, 250,111(1972)$

417) T, Nose ; PJ, 2, 437(1971)

418) S. M. Wolpert et al.; JPS, A-2, 9, 1887(1971)

419) Th. G. Scholte ; JPS, A-2, 10, $519(1972)$

420) O. Yamamoto ; $P J, 2,509(1971)$

421) O. Yamamoto, H. Kambe ; $P J, 2,623(1971)$

422) V. H. Baur $; K-Z, 247,753(1971)$

423) N. Grassie, R. McGuchan ; EPJ, 7, 1091(1971)

424) idem; ibid, 7, 1357(1971)

425) idem; ibid, $7,1503(1971)$

426) idern; ibid, 8, 243(1972) 
427) idem;ibid, 8, 257(1972)

428) F.A.Bell et al, ; $P, 12,579(1971)$

429) A. Seutney;EPJ, 8, 175(1972)

430) idem ; $i$ bid, 8, 163(1972)

431) idem ; ibid, 8, $185(1972)$

432) T. L. Vigo et al.; JAPS, 15, 2051(1971)

433) G. J. Knight, W.W.Wright ; JAPS, 16, 739(1972)

434) idem; ibid, 16, 683(1972)

$435)$ G. G.Cameron, F. Davie ; DMC, $151,289(1972)$

436) 要平占; 漞化, $28,599(1971)$

437) A.M. A. Effat, J.M.Hay ; EPJ, 8, 289(1972)

438) V.Chytry et al.:EPJ, 7, 111(1971)

439) R.J.Gaymans et al, $P, 12,602(1971)$

440) J. Pavlinec, N. J. Kaloforov;EPJ. 7, 1445(1971)

441) 青本, 武内：維学啫，27，486(1971)

442) J. Atkinson, J. R.MacCallum ; JPS, A-2, 10, 811 (1972)

443) R. A. D.Hart, W. W. Wright ; DMC, 153, 237(1972)

444) W. L. Hawkins et al. ; PES, 11,377(1971)

445) W. Berger, C.Ot to; FT, 22, 401(1971)

446) idem ; ibid, 22, $482(1971)$

447) J. Dipietro et al, ;TRJ, 41,593(1971)

448) H. Stepniczka, Jo Dipietro;JAPS, 15, 2149(1971)

449) J. E. Hendrix et al.;TRJ, 41,854(1971)

450) B.Miller, B.C.Goswami ; $T R J, 41,949(1971)$

451) 加滕 5 ; 日化, No，3，523(1972)

452) 広时; 電子写埧, $10,84(1971)$

453) A.M.Herman et al. ; JPS, B, 9, 627(1971)

454) J. Patora et al.; JPS, B, 10, 23(1972)

455) T. Konaga, E. Fukada ; JPS, A-2, 9, 2023(1971)

456) S. Osaki et al.; JPS, A-2, 9, 2099(1971)

457) G. Montando et al, ; $M, 5,203(1972)$

458) R. H. Boyd, C.H. Porter ; TPS, A -2, 10, $647(1972)$

459) H. Sasade et al, $P J, 2,518(1971)$

460) 田息；戴学菲，27,446(1971)

461) 田洎；我学誌, 27,450(1971)

462) 策原; 電子写筫, $10,2(1971)$

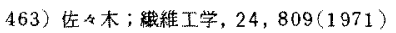

464) 筫沢；工化, 74, 2146(1971)

465) R. S. Stein, R. Prud'homme; JPS, B, 9, 595(1971)

466) L. J. Lynch, N. Thomas ;TRJ, 41, 568(1971)

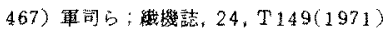

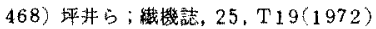

469)稻垣，赥；瀻学誌，27，292(1971)

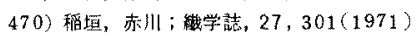

471) 饫路; 維維工学, 24,756(1971)

472) 清造、平；維学誌，28，9(1972)

473) L. J.Lynch et al. ; $K-Z, 248,922(1971)$

474) H.M. Elder et al.; $T R J, 41,653(1971)$

475) W. I. Crewther ; TRI, 42, 77(1972)

476) J. L. Williams, A.Peterlin : JPS, A-2, 9,1483(1971)

477) T. K. Kwei, T. T. Wang ; $M, 5,128(1972)$

478) P.N.Lowell, N.G.McCrum; JPS, A-2, 9, 1935(1971)

479) 镣, 書多村; 白化, Na.1，127(1972)

480) 䋨, 憘多村；日化, No.1，133(1972)

481) 偆, 整多村; 回化, No. 1, 204(1972)

482) 橉田官; 目化, No. 5, 958(1972)

483) H, Ochiai et al. ; JPS, A-2, 9, $1629(1971)$

484 A. T. Serkov, D. N. Kotomina; FT, 22, 434(1971)

485) B. R. Baird et al. ; PES, 11, 274(1971)

486) H. Zimmermann et al, ; FT, 23, 8(1972)

487) B. Philipp et al.; $F T, 23,60(1972)$

488) A.Mally; FT, 22,604(1971)

489) idem : ibid, 22,525(1971)

490) W. Bobeeh t al. ;FT, 23, 35(1972)

491) E.G.Davis, M.L. Rooney; $K-Z, 249,1043(1971)$

492) M. L.D. Santos, D.M. Leitao ; JPS, A-2, 10,769 (1972)

493) M. L.Huggins ; $P, 12,389(1971)$

494) V. Crescenzi et al, : JPS, A-2, 10, 357(1972)

495) 中村占; 轼学誌, 28, $154(1972)$

496) 中村占; 载学薣, 28，160(1972)

497) 根本与; 瀻学誌, 27, 285(1971)

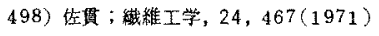

499) T. Sakai et al, JPS, A-2, 10, 253(1972)

500) 息多村的; 䋨学誌, 27,359(1971)

$501)$ 喜多村b; 緎学誌, $27,501(1971)$

502) 喜多村6; 欌学誌, 27,510(1971)

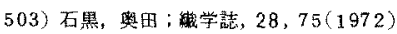

504) 值田的；日化。 No, 6, 1165(1972)

505) A.Frusei et al.; JPS, B, 9, 561(1971)

506) I.A.Abu-Isa:JAPS, 15, 2865(1971)

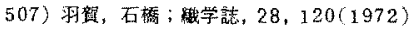

508) 新井; 线維上工篻，4，545(1971)

509) 荻原 6 ; 旦北, No.2，459(1972)

(昭和 47 年 8 月 11 日受理) 